\title{
CULTURE CONDITIONS STIMULATING HIGH $\gamma$-LINOLENIC ACID ACCUMULATION BY SPIRULINA PLATENSIS
}

\author{
Srinivasa Reddy Ronda ${ }^{1}$; S.S. Lele ${ }^{2 *}$ \\ ${ }^{1}$ Koneru Lakshmaiah College of Engineering, Vaddeswaram, Guntur-522502, A.P, India; ${ }^{2}$ University Institute of Chemical \\ Technology, Matunga, Mumbai-400 019, M.H, India
}

Submitted: September 02, 2007; Returned to authors for corrections: December 06, 2007; Approved: November 02, 2008.

\begin{abstract}
Gamma-linolenic acid (GLA) production by Spirulina platensis under different stress-inducing conditions was studied. Submerged culture studies showed that low temperature $\left(25^{\circ} \mathrm{C}\right)$, strong light intensity (6 klux) and primrose oil supplement $(0.8 \% \mathrm{w} / \mathrm{v})$ induced $13.2 \mathrm{mg} / \mathrm{g}, 14.6 \mathrm{mg} / \mathrm{g}$ and $13.5 \mathrm{mg}$ linolenic acid per gram dry cell weight respectively. A careful observation of fatty acid profile of the cyanobacteria shows that, oleic acid and linoleic acid, in experiments with varying growth temperature and oil supplements respectively, helped in accumulating excess $\gamma$-linolenic acid. In addition, cultures grown at increasing light regimes maintained the $\gamma$-linolenic acid to the total fatty acid ratio(GLA/TFA) constant, despite any change in $\gamma$-linolenic acid content of the cyanobacteria.
\end{abstract}

Key words: Gamma linolenic acid, Light intensity, Oil supplementation, Temperature.

\section{INTRODUCTION}

Production of oils from microalgae is an active area of research during recent years (13). The Fatty acid, Gamm-linolenic acid (GLA) is a precursor for prostaglandin E1, an important biologically-active compound necessary for reducing inflammation and blood pressure. Further, GLA is also known for treating various conditions including rheumatoid arthritis (21), eczema (22) and premenstrual syndrome (20). This fatty acid is found primarily in plant-based oils. Nevertheless, owing to their larger area of requirement for cultivation and unpredictable yields, alternative microbial sources have been targeted (5). Several species of fungi (mucor) are known to produce GLA $(3,18)$. However, due to the presence of other polyunsaturated fatty acids in fungal oils, extensive and laborious purification steps are required before arriving at pure fatty acid. In addition, the cost factors behind production of $\gamma$ linolenic acid from fungal source highlight the need for developing alternative routes.

An alternative promising source for GLA production is Spirulina platensis $(4,6)$. Unlike fungi, which should be grown in sophisticated bioreactors, the cyanobacteria can be grown in large open ponds $(2,17)$. The high operating alkaline $\mathrm{pH}$ controls the growth of other unwanted microorganisms (9). Added to the advantage, the isomer of GLA ( $\alpha$-linolenic acid) is found to be absent in total fatty acids of the cyanobacterium. The absence of the fatty acid isomer makes purification simple when GLA is the fatty acid of interest.

The blue green alga is capable of accumulating $1 \%$ of GLA in the dry cell mass. Under specific environmental conditions viz., high light intensity and low temperature, the GLA-to-total fatty acid ratio (GLA/TFA) could be increased up to $31.7 \%$ (7).

Although Harris and James (10) reported the low temperature effect on the fatty acid biosynthesis in plants, information on the role of temperature $(10,12)$ and light intensity $(11)$ on GLA accumulation in the microalga was limited. In addition only a few studies were conducted to evaluate the effect of supplemented oil in the medium on the GLA content of the cyanobacteria. The present work aims to investigate different culture conditions that stimulate the cyanobacteria to produce excess GLA. Also, the work, suggests, oil supplements such as primrose oil as a possible stimulant for excess GLA accumulation by the cyanobacterium.

*Corresponding Author. Mailing address: University Institute of Chemical Technology, Matunga, Mumbai-400 019, M.H, India. Tel.: +919966380444.

E-mail: srinus4@rediffmail.com 


\section{MATERIALS AND METHODS}

\section{Microorganism and Culture Conditions}

Spirulina platensis ARM-740 was obtained from CFTRI, Mysore, India. Medium used for cultivation of cyanobacteria was SOT medium (14) containing (g/l) of $\mathrm{NaHCO}_{3}-16.8, \mathrm{~K}_{2} \mathrm{HPO}_{4}-0.5$, $\mathrm{NaNO}_{3}-2.5, \mathrm{~K}_{2} \mathrm{SO}_{4}-1.0, \mathrm{NaCl}-1.0, \mathrm{MgSO}_{4} \cdot 7 \mathrm{H}_{2} \mathrm{O}-0.2, \mathrm{CaCl}_{2} .2 \mathrm{H}_{2} \mathrm{O}$ $-0.04, \mathrm{FeSO}_{4} .7 \mathrm{H}_{2} \mathrm{O}-0.01$, ethylene di-amine tetra acetate 0.08 and A-5 trace metal solution $1.0 \mathrm{ml}$. The A-5 trace metal solution contained (g/l) $\mathrm{H}_{3} \mathrm{BO}_{3}-2.36, \mathrm{MnCl}_{2} \cdot 4 \mathrm{H}_{2} \mathrm{O}-1.81, \mathrm{ZnSO}_{4} .7 \mathrm{H}_{2} \mathrm{O}$ $0.222, \mathrm{Na}_{2} \mathrm{MoO}_{4} .2 \mathrm{H}_{2} \mathrm{O}-0.039, \mathrm{CuSO}_{4} .5 \mathrm{H}_{2} \mathrm{O}-0.079$ and $\mathrm{Co}\left(\mathrm{NO}_{3}\right)_{2} \cdot 6 \mathrm{H}_{2} \mathrm{O}-0.49$. Experiments on the effect of temperature and oil supplements were performed under light intensity of 1.5 klux. Likewise, experiments on the effect of light intensities were carried at different light intensities ranging from 2-6 klux. Light intensities (i.e., 2, 4 and 6 klux) were accomplished by adjusting the light source (4 Nos. Philips $18 \mathrm{~W}$ light bulbs) near the cultures. All the experiments were carried out at an initial medium $\mathrm{pH} 9.2$ and a growth temperature $33 \pm 1^{\circ} \mathrm{C}$ unless otherwise stated.

\section{Oil Sources}

Refined oils of Sunflower and Peanut were obtained from Godrej Industries and are used for Fatty acid analysis. Evening Primrose oil (Primosa) was procured as a $100 \mathrm{mg}$ capsule and was used in oil supplementation experiments.

\section{Estimation of Biomass}

In all the experiments, biomass was reported in terms of cell concentration, which was calculated using dry cell weight. For estimation of dry cell weight, duplicate samples of cyanobacterial cell suspensions were filtered through pre-weighed microfibre filters (Whatman $\mathrm{GF} / \mathrm{C}$ ), washed with $0.5 \mathrm{~N} \mathrm{HCl}$, dried in an oven at $105^{\circ} \mathrm{C}$ for $4 \mathrm{~h}$ and its final weight recorded.

\section{Lipid Extraction and Transmethylation}

Extraction and lipid trans-methylation $(1,7)$ were carried out on freeze dried samples of Spirulina platensis $(100 \mathrm{mg})$ in a light protected Teflon-lined vial and were further analyzed for fatty acid methylation.

\section{Fatty Acid Methyl Ester (FAME) Analysis}

Gas Chromatography (Chemito $8510 \mathrm{HR}$ ) analysis was done on the extracted fatty acid methyl esters by using an EGSS-X column (14). Components of fatty acid esters were identified by comparing the retention times of authentic fatty acid standards (Sigma \& Co). Quantification of the fatty acids was done using internal standard method with heptadecanoic acid as internal standard. The total fatty acid content was quantified based on the sum of percentages of the evaluated individual fatty acids. The data shown for cell concentration and fatty acid content were mean values of at least two independent samples analyzed in duplicate.

\section{RESULTS AND DISCUSSION}

\section{Effect of Temperature}

Low temperature plays a key role in increasing un-saturation in the fatty acids of the cyanobacteria. Physical and biochemical characteristics of lipid membrane depend on the un-saturation level of the fatty acids (15). Increase in un-saturation can probably be a pre-cautionary measure adopted by microalgae to increase membrane fluidity of the cell (16). The effect of temperature on cyanobacterial fatty acid production was shown in Fig. 1, depicting the GLA content to be increasing with decreasing temperature. The cyanobacteria showed highest GLA (13.2mg/g dry biomass) at $25^{\circ} \mathrm{C}$ as against $10.8 \mathrm{mg} / \mathrm{g}$ at $33^{\circ} \mathrm{C}$. Although GLA content was high at $25^{\circ} \mathrm{C}$, the GLA on volume basis was relatively more at $33^{\circ} \mathrm{C}$ because of higher biomass. Fig. 2 shows the variation of fatty acid composition of the cyanobacteria with temperature. GLA and linoleic acid showed a progressive decrease in fatty acid composition with increase in temperature, while oleic and palmitic acids showed increasing trend with increase in temperature. Clearly, a distinct inverse relationship was established between oleic acid and GLA. The results showed that oleic is major precursor among unsaturated fatty acids for GLA accumulation; GLA increased predominantly at the expense of oleic acid.

\section{Effect of Light Intensity}

Higher light intensities not only increase biomass, but also stimulate cyanobacteria to accumulate larger amount of unsaturated fatty acids. Earlier studies (8) have shown that

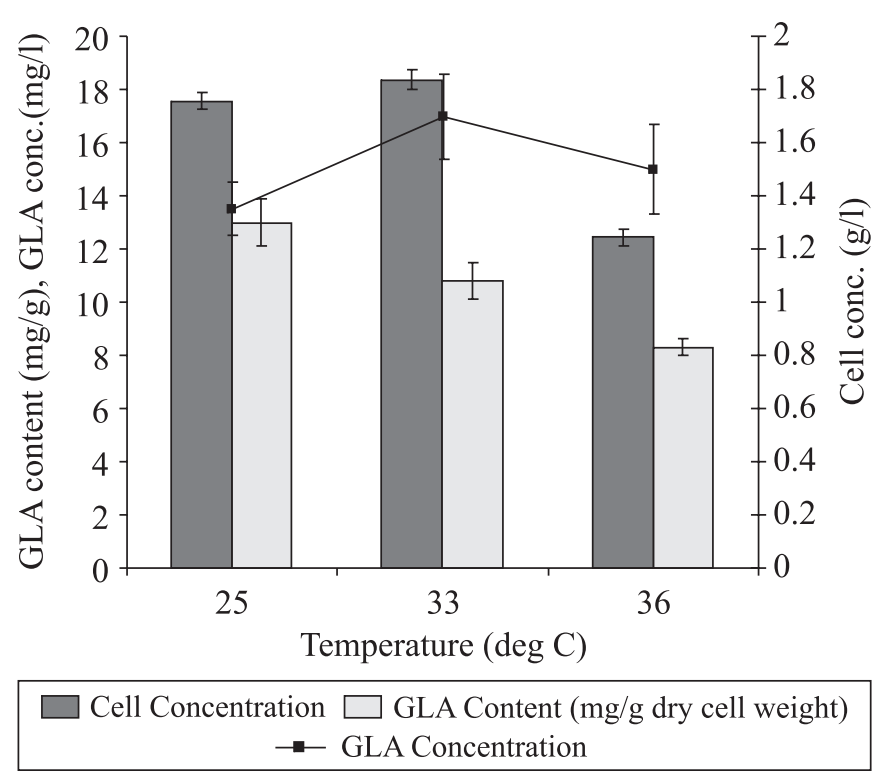

Figure 1. Effect of growth temperature on GLA production by S. platensis. 


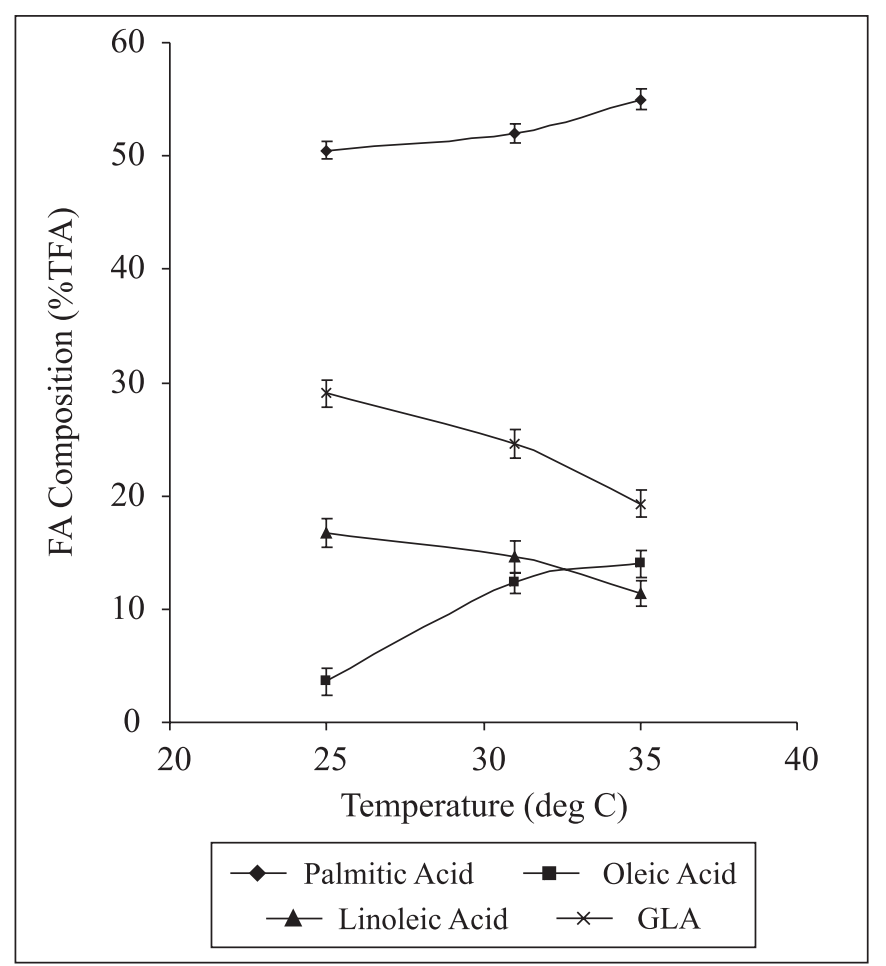

Figure 2. Effect of temperature on fatty acid (FA) profile of S. platensis.

light intensities alter the lipid composition in photosynthetic organisms. Light treatments on the expression level of the four desaturase genes of Synechocystis PCC 6803 (15) proved that light intensities show effect on expression level of desaturase genes which control production of unsaturated fatty acids.

In the present work different light intensities, 2, 4 and $6 \mathrm{klux}$, were considered for studying their effect on GLA production. Fig. 3 shows the effect of light intensity on algal growth (biomass) and GLA production. Although light at 2 and 4 klux stimulated algal growth, only a slight variation in GLA content was observed at these medium light regimes, which is equivalent to the optimal GLA content $(10 \mathrm{mg} / \mathrm{g})$ of the cultures being grown under normal day light conditions. On the other hand, cultures exposed to higher light intensity (6 klux) showed a slight reduction in biomass with concomitant increase in GLA content (14.6 mg/g dry cell weight). The reduction in cell concentration can be attributed to the photo-oxidation of the pigments around this light intensity (6 klux). Within the range of tested light intensities, GLA concentration increased linearly. The increase in GLA concentration at higher light intensity is largely influenced by GLA content (w/w) rather than biomass. At all light intensities, the GLA/TFA ratio was constant despite any change in GLA content. It can be hypothesized that the

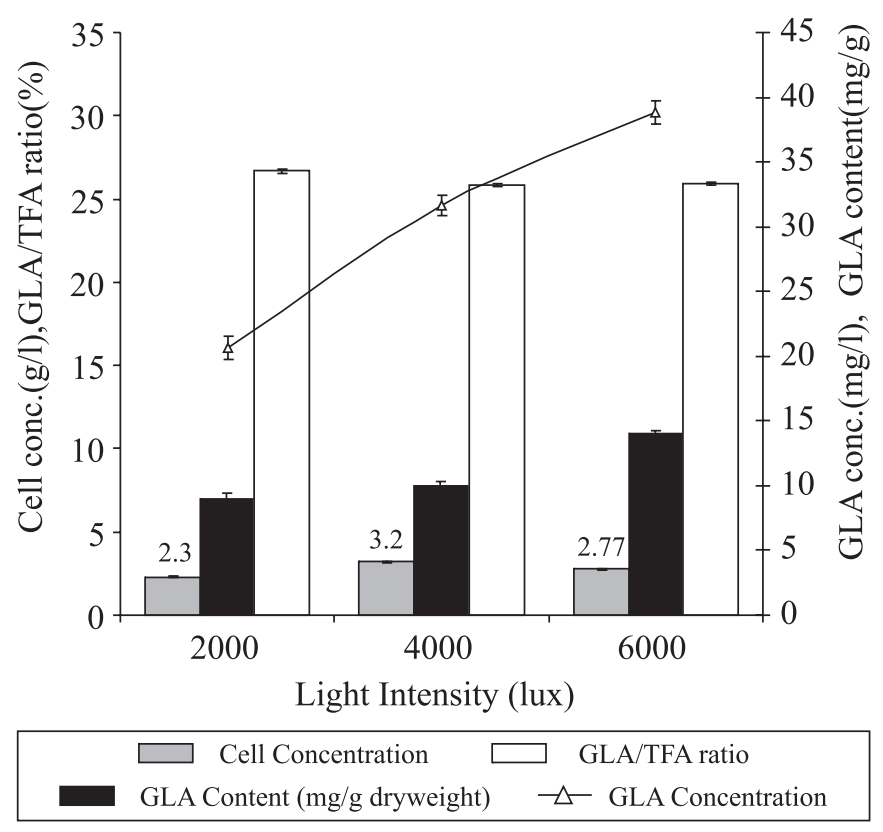

Figure 3. Effect of light intensity on cell concentration, GLA production and GLA/TFA ratio.

alga tries to accumulate more total fatty acids than normal at high light intensities to balance GLA/TFA ratio, which is essential for maintenance of membrane fluidity of the cell. However, restrictions apply on light induced increase in GLA as higher light intensities beyond 6 klux would result in heavy loss in biomass and thus GLA due to permanent damage caused to the cells as a result of photo-oxidation of pigments. Light-dependent changes in fatty acid composition are probably due to the association of activity of photosystems with processes of production and desaturation of fatty acids.

\section{Effect of Oil Supplement on GLA Production}

Supplementation of algal growth media with intermediate fatty acids in the form of oil precursors and their subsequent conversion to desired long chain fatty acids offers a better approach for studying their effect on desired fatty acid biosynthesis than having to test the effect of conventional carbon sources on synthesis of fatty acids de novo. As linoleic acid can be converted to $\gamma$-linolenic acid, the uptake of the oil and subsequent conversion of linoleic acid to GLA can be tested. Different plant oils having high linoleic content, viz., peanut, sunflower and primrose oil were analyzed using gas chromatography (Table 1). The results showed that primrose oil has maximum linoleic acid ( $82.7 \%$ of TFA) with little GLA (3.4\% of TFA). The low GLA content supports the assumption that during microalgal cultivation in medium with primrose any increase in GLA in the cyanobacterial biomass beyond normal 
Table 1. Gas Chromatography analysis of different oils.

\begin{tabular}{lccc}
\hline $\begin{array}{c}\text { \% Fatty acid in } \\
\text { Total fatty acids }\end{array}$ & Sunflower & Peanut & $\begin{array}{c}\text { Evening } \\
\text { Primrose }\end{array}$ \\
\hline Palmitic(C16:0) & $7.0 \pm 0.6$ & $15.5 \pm 0.9$ & $6.90 \pm 0.6$ \\
Stearic acid(18:0) & $0.2 \pm 0.8$ & $2.8 \pm 0.6$ & $1.36 \pm 0.3$ \\
Oleic acid(C18:1) & $33.0 \pm 1.1$ & $45.5 \pm 1.3$ & $5.54 \pm 0.8$ \\
Linoleic(C18:2) & $59.0 \pm 1.4$ & $36.0 \pm 0.6$ & $* 82.70 \pm 0.4$ \\
GLA(C18:3) & - & - & $3.40 \pm 0.3$ \\
\hline$\%$ Total unsaturation & 92.0 & 81.5 & 91.64 \\
\hline
\end{tabular}

* Linoleic acid as major fatty acid in primrose oil; (-) Undetected.

was not a possible cross contamination of the oil with the biomass. Also during fatty acid analysis, a supplementary precaution was taken by washing biomass with alcohol and hexane before freeze-drying, to avoid cross contamination of GLA in biomass with external GLA if present in the oil.

With the best suited oil of Primrose as a source for linoleic acid (C18: 2), a series of experiments was conducted to observe its effect on algal growth and fatty acid production.

As shown in Fig. 4a cyanobacteria grown in primrose oil at $0.8 \%(\mathrm{w} / \mathrm{v})$ accumulated maximum GLA $(13.5 \mathrm{mg} / \mathrm{g}$ dry cell

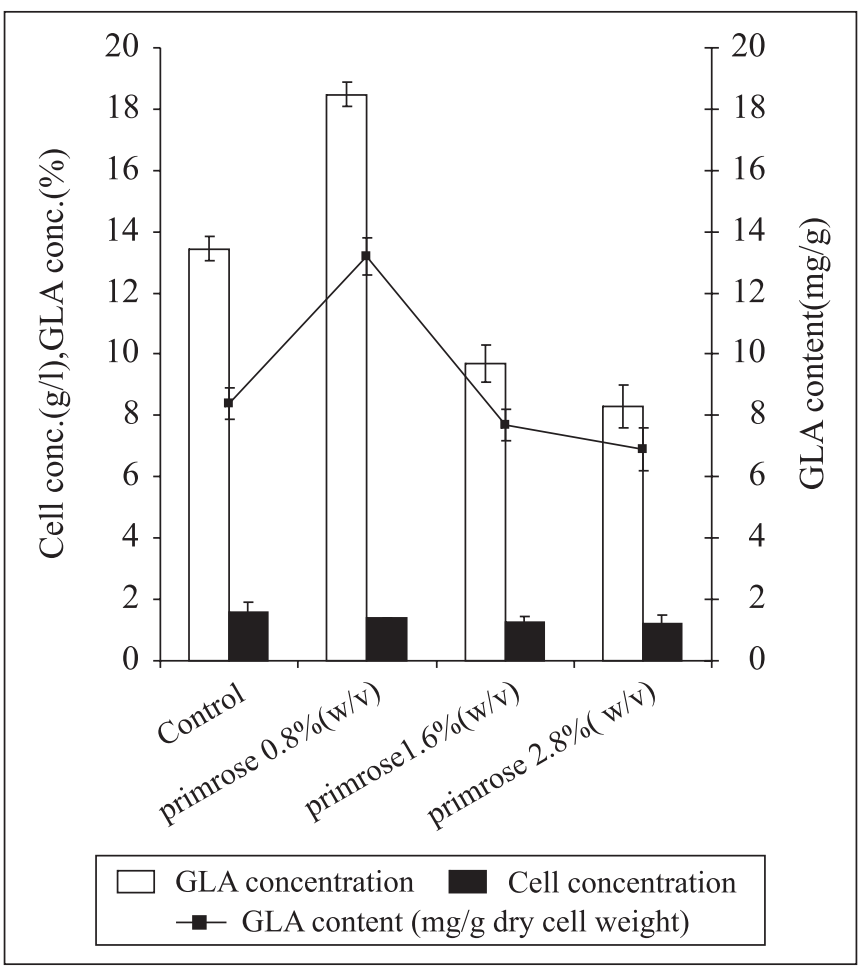

Figure 4a. GLA production in various supplemented concentrations of primrose oil in submerged cultures. weight) when compared to either the control or other oilsupplemented cultures. Although, growth was hardly affected in all the oil-grown cultures, which was reflected in their final cell concentrations, GLA production (on volume basis) increased in the culture containing $0.8 \%(\mathrm{w} / \mathrm{v})$ primrose at the cost of increased GLA content (GLA per unit dry biomass). The decline in GLA content at higher oil concentration can be attributed to the increased porosity and subsequent cell lysis due to extraction of membrane proteins. However, in case of $0.8 \%$ (w/ v) primrose supplemented culture, the rise in GLA content can be attributed to the controlled intake of oil supplement and subsequent utilization of precursor component (linoleic acid) for GLA synthesis. The fatty acid profiles (Fig. 4b) of the cyanobacteria grown as control (without oil) and culture grown in supplemented primrose oil show that the alga accumulated higher GLA as well as linoleic acid in $0.8 \%(\mathrm{w} / \mathrm{v})$ primrose supplemented culture supporting the suggested method of oilintake. The results revealed that linoleic acid could act as a precursor for excess GLA synthesis in oil-supplemented cultures. Data in Table 2 gives a comparison of the GLA content of the microalgal strain under different culture conditions. Although experiments with temperature and oil supplementation showed high GLA accumulation in the cyanobacteria, light induced GLA from this study was the highest and is comparable to results from the other reported studies with different conditions as tabulated herein.

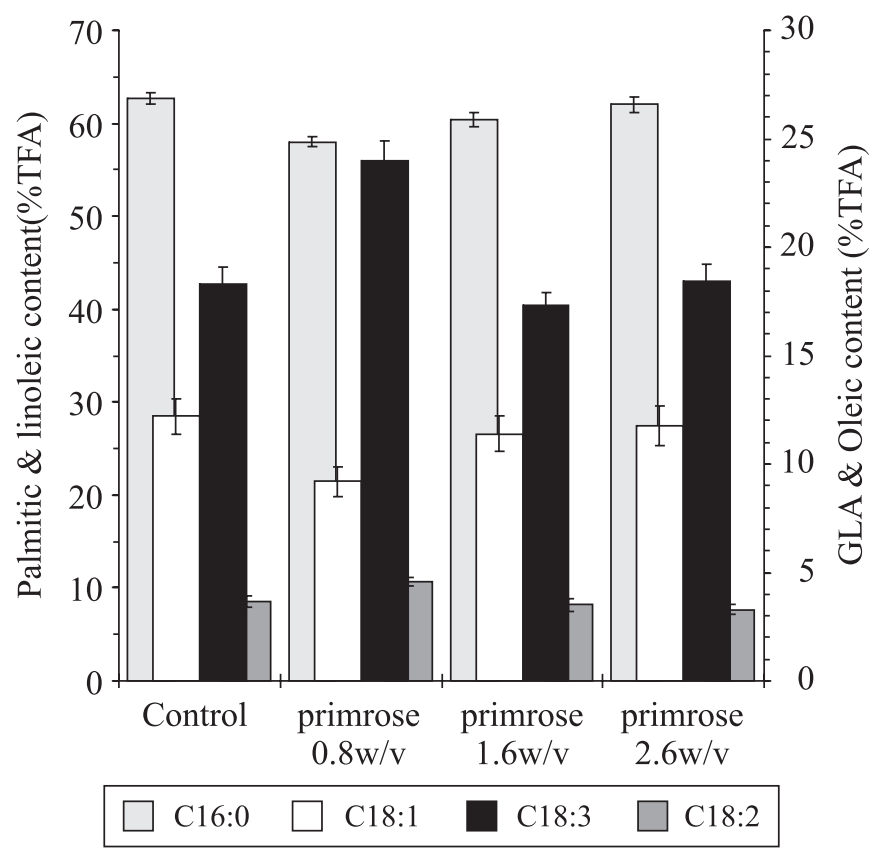

Figure 4b. Fatty acid profile of $S$. platensis grown in different supplemented oil concentrations. 
Table 2. Comparison of GLA content in Spirulina platensis under different cultivation conditions.

\begin{tabular}{lcc}
\hline \multicolumn{1}{c}{ Conditions Tested } & $\begin{array}{c}\text { GLA Content } \\
(\mathrm{mg} / \mathrm{g})\end{array}$ & Reference \\
\hline Effect of Herbicide & 14.0 & $(4)$ \\
Effect of Urea & 13.5 & $(14)$ \\
Effect of Light and Dark Cycles & 16.0 & $(19)$ \\
Effect of Light Intensity & 14.6 & \\
Effect of Primrose Oil & 13.5 & Present Work \\
Effect of Temperature & 13.2 & \\
\hline
\end{tabular}

\section{RESUMO}

\section{Condições de cultura simulando o levado acúmulo de ácido $\gamma$-linolênico por Spirulina platensis}

Estudou-se a produção de ácido g-linolênico por Spirulina platensis em diferentes condições de estresse. Culturas submersas indicaram que temperatura baixa $\left(25^{\circ} \mathrm{C}\right)$, forte intensidade de luz (6 klux) e suplementação com óleo de prímula $(0,8 \% \mathrm{p} / \mathrm{v})$ induziram a produção de ácido linolênico de $13,2 \mathrm{mg} /$ $\mathrm{g}, 14,6 \mathrm{mg} / \mathrm{g}$ e $13,5 \mathrm{mg} / \mathrm{g}$ peso seco, respectivamente. Uma observação cuidadosa do perfil de ácidos graxos da cianobacteria indica que os ácidos oléico e linoléico, em experimentos com diferentes temperaturas de crescimento e suplementos de óleo, auxiliaram no acúmulo de excesso de ácido $\gamma$-linolênico. Além disso, as culturas obtidas em intensidades crescentes de luz mantiveram a relação ácido $\gamma$-linolênico/ácidos graxos totais constante, independentemente de qualquer mudança no conteúdo de ácido $\gamma$-linolênico da cianobactéria.

Palavras-chave: ácido $\gamma$-linolênico, intensidade de luz, suplementação com óleo, temperatura

\section{REFERENCES}

1. Ana, I.C.; Garcia, C. (2000). Development in Lipid Analysis: Some New Extraction Techniques and in situ Transesterification. Lipids, 35(11), 1167-1175.

2. Borowitzka, M.A. (1999). Commercial production of microalgae: ponds, tanks, tubes and fermenters. J. Biotechnol., 70 (1-3), 313-321.

3. Carvalho, P.O.; Oliveira, J.G.; Pastore, G.M. (1999). Enhancement of Gamma-Linolenic Acid production by the fungus Mucor sp LB-54 by growth temperature. Rev. Microbiol., 30 (2), 170-175.

4. Cohen, Z.; Didi, S.; Heimer, Y.M. (1992). Overproduction of $\gamma$ Linolenic acid and Eicosapentanoic acids by algae. Plant Physiol., 98 (2), 569-572.
5. Certik, M.S.; Shimizu, S. (1999). Biosynthesis and regulation of microbial polyunsaturated fatty acid production. J. Biosci. Bioeng., 87 (1), 1-14.

6. Qiang, H.; Zhengyu, H.; Cohen Z.; Richmond, A. (1997). Enhancement of eicosapentaenoic acid (EPA) and gamma-linolenic acid (GLA) production by manipulating algal density of outdoor cultures of Monodus subterraneus (Eustigmatophyta) and Spirulina platensis (Cyanobacteria). Eur. J. Phycol., 32 (6), 81-86.

7. Cohen, Z.; Reungjitchachawali, M.W.; Siangdung, W.; Tanticharoen, M. (1993). Production and partial purification of $\gamma$-Linolenic acid and some pigments from Spirulina platensis J. Appl. Phycol., 5 (1), 109-115.

8. Constantopoulos, G.; Boloch, K. (1967). Effect of light intensity on the lipid composition of Euglena gracilis. J. Bio.Chem., 242, 35383542 .

9. Goksan, T.; Zekeryaolu, A.; lknur, A.K. (2007). The Growth of Spirulina platensis in DifferentCulture Systems under Green house Condition. Turk J. Biol., 31 (1), 47-52.

10. Harris, P.; James, A.T. (1968) The Effect of low Temperatures on Fatty acid Biosynthesis in plants. Biochem. J., 112, 325-330.

11. Ioannis, T.; Niels De, P.; Patrick, S. (2003). Optimization of T-ISO biomass production rich in essential fatty acids II. Effect of different light regimes on the production of fatty acids. Aquacult., 216 (1-4), 223-242.

12. Quoc, K.P.; Dubacq, J.P. (1997). Effect of growth temperature on the biosynthesis of eukaryotic lipid molecular species by the cyanobacterium Spirulina platensis. Biochim. Biophys. Acta, 1346 (3), 237-246.

13. Molina, G.E.; Belarbi, E.H.; Acien Fernandez, F.G.; Medina, R.A.; Chisti, Y. (2003) Recovery of microalgal biomass and metabolites: process options and economics. J. Biotechnol., 20 (7-8), 491-515.

14. Mahajan, G.; Kamat, M. (1995). $\gamma$-linolenic acid production from Spirulina platensis. Appl. Microbiol. Biotechnol., 43 (3), 466-469.

15. Mihaly, K.; Otto, Z.; Tibor, F.; Hajime, W.; Nagay, F.; Gombos, Z. (1998). Light-induced expression of fatty acid desaturase genes. Proc. Natl. Acad. Sci., 95 (8), 4209-4214.

16. Nichols, B.W.; Wood, B.J.B. (1968). The occurrence and biosynthesis of gamma-linolenic acid in a blue-green alga, Spirulina platensis. Lipids, 3 (1), 41-50.

17. Richmond, A. (1992). Open systems for the mass production of photoautotrophic microalgae outdoors: physiological principles. $J$. Appl. Phycol., 4 (3), 281-286.

18. Somashekar, D.; Venkateshwaran, G.; Sambaiah, K.; Lokesh, B.R. (2002). Effect of culture conditions on lipid and gamma-linolenic acid production by mucoraceous fungi. Process Biochem., 38 (12), 1719-1724.

19. Tanticharoen, M.; Reungjitchachawali, M.; Boonag, B.; Vonktaveesuk, P.; Vonshak, A.; Cohen, Z. (1994). Optimization of $\gamma$-linolenic acid (GLA) production in Spirulina platensis. J. Appl Phycol., 6 (3), 295-300.

20. Wang, M.; Hammarback, S.; Lindhe, B.A.; Backstrom, T. (1995). Treatment of Premenstrual Syndrome by Spironolactone: A DoubleBlind, Placebo-Controlled Study, Acta. Obstet. Gynecol. Scand., 74 (10), 803-808.

21. Zurier, R.B.; Rossetti, R.G.; Jacobson, E.W.; DeMarco, D.M.; Liu, N.Y.; Temming, J.E.; White, B.M.; Laposata, M. (1996). Gammalinolenic acid treatment of rheumatoid arthritis. A randomized, placebo-controlled trial. Arthritis Rheum., 39: 1808-1817.

22. Worm, M.; Henz, B.M. (2000). Novel unconventional therapeutic approaches to atopic eczema. Dermatology, 201 (3), 191-195. 